\title{
The effect of intramammary infection with coagulase-negative staphylococci in early lactating heifers on milk yield throughout first lactation revisited
}

\author{
S. Piepers, ${ }^{\star 1}$ Y. H. Schukken, $†$ P. Passchyn, ${ }^{\star} \ddagger$ and S. De Vliegher* \\ ${ }^{*}$ M-team and Mastitis and Milk Quality Research Unit, Department of Reproduction, Obstetrics, and Herd Health, Faculty of Veterinary Medicine, \\ Ghent University, 9820 Merelbeke, Belgium \\ †Quality Milk Production Services, Department of Population Medicine and Diagnostic Sciences, College of Veterinary Medicine, \\ Cornell University, Ithaca, NY 14853 \\ łlndependent Dairy Consultant, Milk@vice, 8820 Torhout, Belgium
}

\section{ABSTRACT}

The objective of this study was to further scrutinize the previously found positive association between intramammary infection (IMI) caused by coagulase-negative staphylococci (CNS) in early lactating heifers and test-day daily milk yield (MY) throughout first lactation, with a specific focus on the effect of the heifers' genetically determined milk production levels and the incidence of clinical mastitis. Two precise longitudinal data sets were analyzed using a series of statistical models including potential confounding and intermediate variables. The final database included the IMI status at calving, composite milk somatic cell count (SCC) and MY records at test day up to $285 \mathrm{~d}$ in milk (DIM), farmer-recorded clinical mastitis (CM) cases between 14 and 285 DIM, estimated new IMI incidence based on a SCC threshold of 100,000 cells/mL between 14 and 285 DIM, DIM, average 305-d MY at the herd level, and the heifers' genetic merit for MY from 240 dairy heifers from 29 dairy herds. Seventy-one (29.6\%) early lactating heifers were noninfected, 108 heifers (45.0\%) were CNS infected, and 61 heifers $(25.4 \%)$ were infected with any major pathogen. The positive effect of CNS IMI in early lactation on test-day MY was estimated at $1.32 \mathrm{~kg} / \mathrm{d}$ using a first basic mixed regression model. Correcting for the confounder genetic merit for MY reduced this effect to $1.17 \mathrm{~kg}$. Interestingly, taking into account the confounding effect of herd resulted in an increase of the estimate from 1.32 to $2.2 \mathrm{~kg} / \mathrm{d}$. The positive effect of CNS IMI in early lactation on MY after correcting the model for both confounders was estimated at $2.05 \mathrm{~kg} / \mathrm{d}$. Heifers infected with CNS in the first DIM tended to have fewer CM cases throughout lactation compared with the noninfected herd mates. Including the intermediate variable $\mathrm{CM}$ in the model explained $0.16 \mathrm{~kg} / \mathrm{d}$ of the corrected effect of $2.05 \mathrm{~kg} / \mathrm{d}$.

Received January 30, 2013.

Accepted May 5, 2013.

${ }^{1}$ Corresponding author: Sofie.Piepers@UGent.be
Inclusion of test-day SCC, another intermediate variable, however, increased the estimate by $0.11 \mathrm{~kg} / \mathrm{d}$. With an appropriate correction for several confounders and biologically understood intermediate variables such as CM, test-day SCC, and new IMI based on SCC threshold of 100,000 cells/mL, an unexplained test-day MY difference between CNS-infected and noninfected heifers of $2.0 \mathrm{~kg} / \mathrm{d}$ remained.

Key words: coagulase-negative staphylococci, heifer, intramammary infection, milk yield

\section{INTRODUCTION}

Intramammary infections in dairy heifers are highly prevalent, which contradicts the once generally accepted thought that heifers' udders were sterile (De Vliegher et al., 2012). In several heifer mastitis surveys conducted throughout the world, 12 to $57 \%$ of quarters were shown to harbor an IMI at the time of calving (e.g., Cook et al., 1992; Parker et al., 2007). Most of those IMI revealed themselves as subclinical mastitis characterized by an elevated SCC without any other visible symptoms of inflammation (De Vliegher et al., 2012). Heifers with an elevated SCC between 5 and 14 DIM had higher test-day SCC and encountered more cases of subclinical mastitis (De Vliegher et al., 2004), produced less milk (De Vliegher et al., 2005b), and were more at risk of being culled during first lactation (De Vliegher et al., 2005a). Follow-up work hypothesized (Piepers et al., 2009) and substantiated by use of culture data (Piepers et al., 2010) that the impact of IMI in early lactation strongly depends on the mastitis pathogens that are involved.

The vast majority of IMI in early lactating heifers is caused by CNS (Fox, 2009). Coagulase-negative staphylococci are a heterogeneous group of at least 50 different species and subspecies of which approximately 10 are frequently found in bovine milk samples (Piessens et al., 2011) and are abundantly present on teat apices (Braem et al., 2012, 2013). Although evidence exists that some species compromise udder health more than 
others in cows (Supré et al., 2011) and goats (Koop et al., 2012), CNS as a group are still considered as relatively harmless minor pathogenic skin flora opportunists (Schukken et al., 2009). Heifers that freshened with CNS IMI had a slightly higher average test-day SCC throughout first lactation compared with noninfected heifers, but encountered fewer cases of clinical mastitis (CM) throughout their first lactation (Piepers et al., 2010). The CNS-infected heifers in early lactation actually outproduced their noninfected herd mates (Piepers et al., 2010), despite the increase in test-day SCC, which is, in general, negatively correlated with milk production (Green et al., 2006). Strikingly, higher milk yield (MY) in CNS-infected heifers and multiparous cows compared with noninfected animals were observed by others as well, although the actual production effects in those studies was somewhat variable (Compton et al., 2007; Schukken et al., 2009; Paradis et al., 2010).

Some hypotheses for the surprising MY differences have been proposed. First, a lower incidence of CM throughout lactation was hypothesized (Piepers et al., 2010) to result in a lower MY loss, which could, in turn, be interpreted as an indirect MY increase (Wilson et al., 2004). Protective effects of preexisting CNS IMI against new IMI were reported in previous studies (Matthews et al., 1991; Schukken et al., 1999) but could not be observed in others (Hogan et al., 1988; Zadoks et al., 2001). The discrepancy between the results might be partly explained by differences in study design and challenge conditions among the studies. Based on a recent meta-analysis in which the effect of IMI with minor mastitis pathogens on the acquisition of new IMI with major mastitis pathogens was examined, observational studies seem to show no protective effect, whereas challenge studies seem to show strong and significant protective effects of CNS IMI, specifically when major pathogens were introduced into the mammary gland via methods bypassing the teat end (Reyher et al., 2012). Second, Compton and coworkers (2007) suggested that high-producing heifers could be more susceptible to CNS IMI compared with lowproducing ones. In this regard, cows affected with CM caused by CNS were previously shown to produce more milk before the clinical symptoms appeared than the healthy control group (Gröhn et al., 2004). The latter would imply that the heifers' genetically determined milk production levels confound the association between CNS IMI and MY and that CNS IMI themselves are neither directly nor indirectly responsible for the increased MY in CNS-infected heifers. Although both hypotheses are plausible, neither have been confirmed nor refuted.

The objective of this study was to further scrutinize the previously observed positive association between
CNS IMI in early lactating heifers and test-day MY throughout first lactation (Piepers et al., 2010), with a specific focus on the effect of the potentially higher genetically determined milk production levels and lower incidence of CM in CNS-infected heifers. This was done by extending the existing data set with data obtained from another precise longitudinal field study and by including several other potential confounding and intermediate variables with the genetic merit for milk production and the incidence of $\mathrm{CM}$, respectively, as the potential confounding and intermediate variable of main interest.

\section{MATERIALS AND METHODS}

\section{Herds, Heifers, and Data}

Data from 2 longitudinal studies conducted in Flanders (Belgium) were combined into one data set.

Herds. Information on the herds used in the first study has been described in detail elsewhere (Piepers et al., 2010). Briefly, 20 commercial dairy herds located in East Flanders were included and the study was designed to gain more in-depth insights into the epidemiology of subclinical mastitis in fresh dairy heifers (Piepers et al., 2010, 2011). The data set from the current study was expanded with data from a second precisely conducted longitudinal study including 10 commercial dairy herds, located in West Flanders within a radius of 20 $\mathrm{km}$ around Torhout (Belgium; P. Passchyn, S. Piepers, and S. De Vliegher, unpublished data). Herd owners were approached for their willingness to participate in a clinical trial on the effect of systemic prepartum treatment of dairy heifers. Herds that participated in one or the other study needed to meet following requirements: (1) participation in the DHI program in Flanders on an annual basis, with an interval of 4 to 6 wk between 2 test days, (2) presence of a good animal identification and registration system, (3) record keeping of all health issues that occur on the farm (date of occurrence, identification number of animal, diagnosis, and treatment), and (4) absence of treating heifers with antimicrobials before calving (Table 1).

Heifers. In the first study, 191 heifers with an average of 9 heifers per herd (ranging between 4 and 10 per herd) were selected according to their expected calving date between March 2006 and December 2007 (Table 1). In the second study, 229 heifers (21 to 24 heifers per herd) were included. Only the 153 nontreated heifers were considered to be eligible for inclusion in the current study.

Data. In the first study, consecutive quarter milk samples were aseptically collected by the first author at 1 to 4 DIM and at 5 to 8 DIM to diagnose IMI, 
Table 1. Structure and descriptive statistics of the data sets included in the analyses

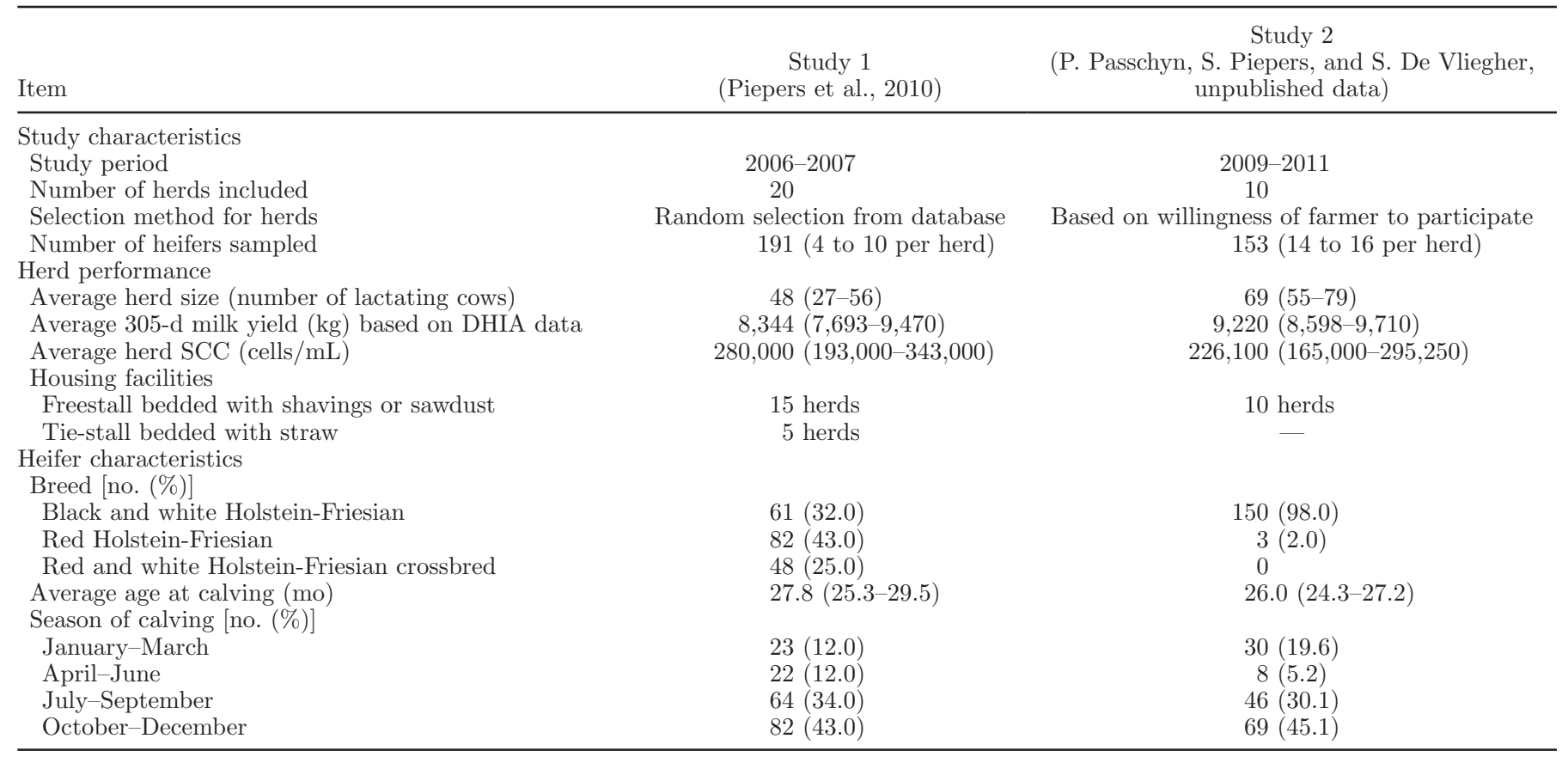

whereas in the second study duplicate quarter milk samples were taken between 1 and 3 DIM. All milk samples were collected before morning milking after disinfection of the teats and after the first streams of milk were discarded, were immediately stored at $4^{\circ} \mathrm{C}$, and transported under cooled conditions to the laboratory. Composite milk SCC and average test-day MY were recorded on a 4 - to 6 -weekly basis as part of the DHI program. Milk SCC was quantified by electronic counting (Fossomatic 5000; Foss Electric A/S, Hillerød, Denmark) at the Milk Control Centre Flanders (Lier, Belgium). The index for the genetic merit for MY (GEN) was available from the breeding values of the sires from the official progeny-testing recordings based on the performances of their daughters in first lactation (CRV, Oosterzele, Belgium). Genetic merit for MY was considered as a within-herd, dichotomous variable. Heifers were classified as high and low yielding based on the median value calculated for each herd separately. Clinical mastitis cases were detected by the farmer based on local or systemic clinical signs during the first 285 DIM or until culling. The date of occurrence, the identification number of the heifer and the affected quarter(s) were recorded. Heifers with CM were treated by the farmer according to the protocol the farmer normally uses. The incidence rate of $\mathrm{CM}$ was calculated and expressed as the number of quarter cases per 10,000 heifer-days at risk from 14 to 285 DIM. A case of CM in the same quarter was defined as a new case whenever the interval between both cases was $\geq 14$ d (Barkema et al., 1998). Clinical mastitis cases in a different quarter within the same heifer were considered as a new case independently of the time interval. Heifer-days at risk were calculated as the total number of days a heifer was present in the herd, starting from parturition to 285 DIM, minus $14 \mathrm{~d}$ after each case of CM. A heifer had an estimated new IMI (NIMI) when its test-day SCC was $>100,000$ cells $/ \mathrm{mL}$ when the previous count recorded had been less than the threshold. The average 305-d MY at the herd level (305MY) was calculated from the DHI-records including both heifers and multiparous cows. Herds were classified as being high or low yielding based on the median value ( $>$ or $\leq 8,258 \mathrm{~kg}$, respectively) of all herds.

\section{Definition of IMI Status}

Bacteriological culture was performed in both studies as previously described (Piepers et al., 2007).

Quarters. A quarter was considered as being infected with CNS or a major pathogen if CNS or the same major pathogen, respectively, were isolated from either the 2 consecutive samples in the first study or the duplicate samples in the second study. When either the 2 consecutive milk samples or the duplicate milk samples were contaminated the data for that quarter were considered missing. Both studies originally defined the infection status of quarters that were culture positive in only 1 of the 2 samples somewhat differently. In the first study, such quarters were not considered as 
being infected and were allocated to 4 separate classes based on the culture result: single CNS positive at first sampling, single CNS positive at second sampling, single major pathogen positive at first sampling, and single major pathogen positive at second sampling (Piepers et al., 2010). Gram-negative bacteria and Bacillus spp. were excluded from the analyses in that study. In the second study, isolation of a mastitis pathogen from only one of the duplicate milk samples was considered nonsignificant growth and outcomes of quarters with nonsignificant growth were combined with no growth for defining the final quarter IMI status. In the second study, the percentage of all duplicate pairs sampled in disagreement, inclusive the culture-negative pairs, was less than $5.0 \%$. As the added value of the duplicate sample collected in the second study seems to be rather negligible, it was decided to redefine the quarter IMI status in the first study based on the first culture result only to harmonize the IMI status definition between both studies as much as possible.

Heifers. A heifer was considered to be infected in early lactation with either CNS or a major pathogen if at least one quarter was infected with CNS or a major pathogen, respectively. Uninfected and CNS infected heifers from which one or more values from functional quarters were missing were excluded from the analyses. Heifers with at least one quarter that was infected with CNS and no quarters infected with a major pathogen were considered to be infected with CNS. Heifers with at least one quarter that was infected with a major pathogen were considered to be infected with a major pathogen, whatever the infection status of the other quarters.

\section{Data Analysis}

Causal Structure. A causal structure was formulated based upon the 2 hypotheses potentially explaining the higher test-day MY in CNS-infected animals compared with uninfected herd mates (Figure 1). The causal diagram contains test-day MY until 285 DIM as the outcome variable and CNS IMI status in early lactation as the predictor variable of main interest, with GEN, herd, study (differentiation between study 1 and 2), and $305 \mathrm{MY}$ as potential confounders, and CM, NIMI, and test-day natural logarithm-transformed SCC (LnSCC) as potential intermediate variables. Arrows represent the hypothesized directional causal relationships between variables. Heifer was considered separately and included as a random effect to account for the repeated nature of the test-day MY data. The causal diagram was carefully quantified using a series of models described in more detail below. Of particular interest was the change in the regression parameters for
CNS IMI when potential confounders or intermediate variables were included in the basic model.

Statistical Analyses. First, a linear mixed regression model and 2 Cox proportional hazard models were fit to determine the association between CNS IMI in early lactation and LnSCC at test day (Equation 1), and time to estimated CM (Equation 2; 1 = clinical mastitis event; $0=$ censored) and NIMI (Equation 3; 1 $=$ estimated NIMI event; $0=$ censored), respectively, in the first 285 DIM or until culling:

$Y_{i j k}=\beta_{0}+\mu_{\text {herd }(j)}+\mu_{\text {heifer }(k)}+\beta_{1} \mathrm{DIM}+\beta_{2} \mathrm{IMI}+e_{i j k}$,

where $Y_{i j k}$ is the observed value for $\operatorname{LnSCC}$, with $\mu_{\operatorname{herd}(j)}$ is the random effect of the herd $i$ ( $i=1$ to 29 ; random statement), $\mu_{\text {heifer }(k)}$ is the random effect of the heifer $j$ $(j=1$ to 240$)$ to correct for within-heifer correlation of subsequent 4 - to 6 -weekly test-day milk recordings $k$ (repeated statement), $\beta_{0}$ is the intercept (overall mean), $\beta_{1}$ and $\beta_{2}$ are the regression coefficients of the fixed effects, DIM is the DIM in nine 30-d categories (9 levels: $15-45,46-75,76-105$, 106-135, 136-165, $166-195,196-225,226-255$, or $256-285$ DIM), IMI is the fixed effect of the IMI status of the heifer (3 levels: noninfected, infected with CNS, or infected with major pathogen), and $e_{i j k}$ is the random error term, assumed to be normally distributed with mean 0 and variance $\sigma^{2}$.

$$
\lambda_{i j}(t)=\lambda_{i 0}(t) \exp \left(\beta \mathrm{IMI}_{j(i)}\right), \quad[2] \text { and [3] }
$$

where $\lambda_{i j}(t)$ is the hazard of contracting a CM (Equation 2) or estimated NIMI (Equation 3) as outcome variables, respectively, at $t \mathrm{DIM} ; \lambda_{i 0}(t)$ is the baseline hazard function for herd $i(i=1$ to 29$)$ as a stratum; and $\mathrm{IMI}_{j(i)}$ is the fixed effect of the IMI status of the heifer $j(j=1$ to 240) within herd $i$. Hazard ratios (HR) with $95 \%$ confidence intervals were calculated and a Kaplan-Meier survival graph was generated.

Second, different linear mixed models were fit to determine the effect of the potential confounders GEN (potential confounder of main interest), herd, study, and $305 \mathrm{MY}$ on the estimate of CNS IMI in early lactation on test-day MY between 14 and 285 DIM using SAS (version 9.3; SAS Institute Inc., Cary, NC; PROC MIXED). Each potential confounder was added to the basic model (Equation 4) and then again removed and replaced by the next one.

$$
Y_{j k}=\beta_{0}+\mu_{\text {heifer }(k)}+\beta_{1} \mathrm{DIM}+\beta_{2} \mathrm{IMI}+e_{j k},
$$

where $Y_{j k}$ is the observed value for the test-day MY $(\mathrm{kg} / \mathrm{d})$ and DIM, IMI is as in Equation 1, and $e_{j k}$ is the 


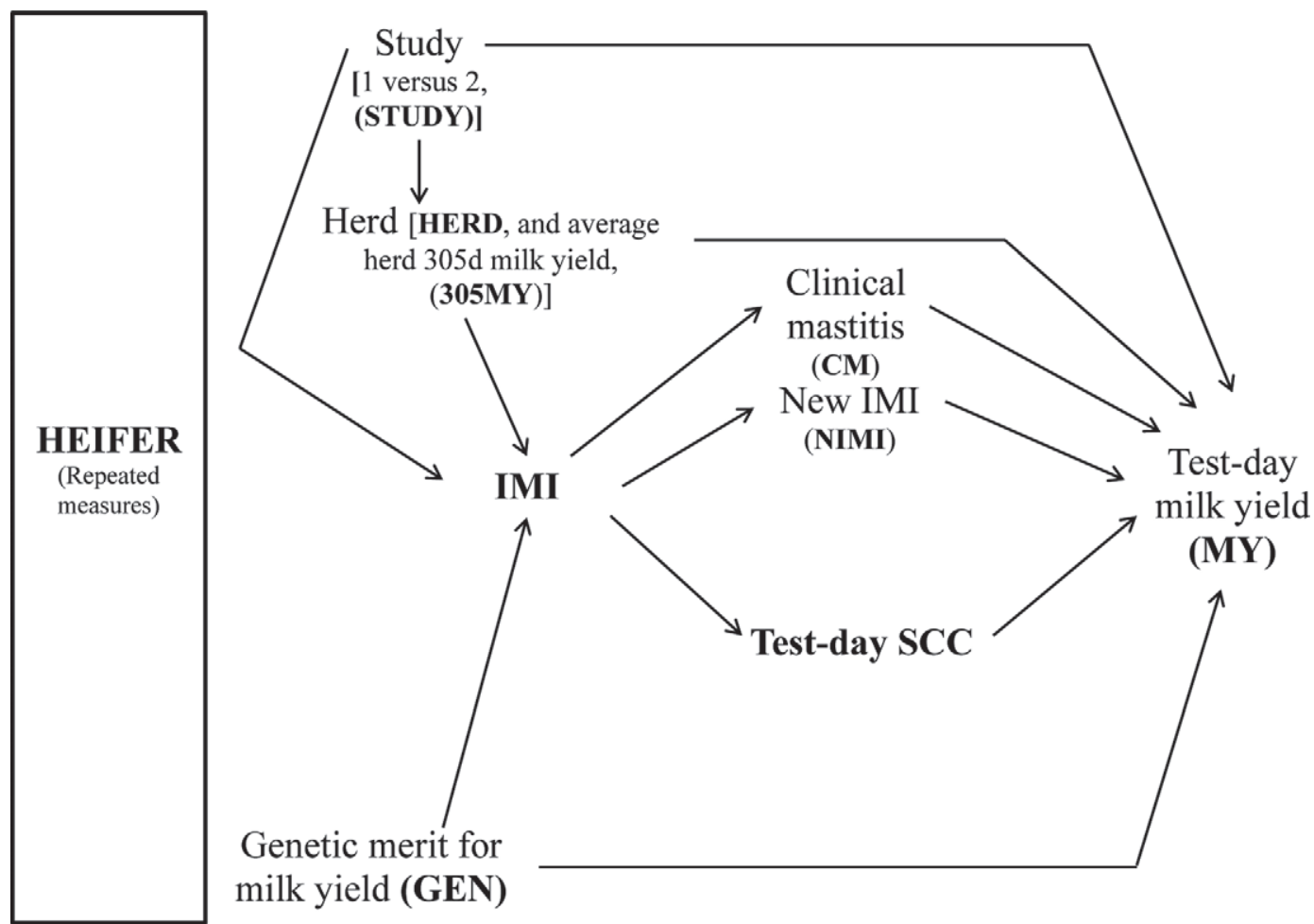

Figure 1. Causal structure of postulated pathways between the heifers' IMI status (noninfected vs. infected with CNS) in early lactation and the test-day milk yield between 14 and 285 DIM. The variables GEN, herd, study, and 305MY were included in the regression models as potential confounders. The variables CM, test-day SCC, and NIMI were included in the regression models as potential intermediate variables. The control variable heifer (boxed) was included in all regression models to control for the clustering of repeated measurements within a heifer.

random error term, assumed to be normally distributed, with mean 0 and variance $\sigma^{2}$. Subsequently, all potential confounders that were significantly associated with test-day MY in the above-mentioned model at a $P<0.05$ were added together. Nonsignificant variables were omitted using a backward stepwise approach to eventually end up with a basic model corrected for the significant confounders (defined as model 5).

Third, further models were fit to quantify the effect of the potential intermediate variables of $\mathrm{CM}$ (potential intermediate variable of main interest), LnSCC, and NIMI on test-day MY. Each potential intermediate variable was added to model 5 and then again removed and replaced by the next one. Clinical mastitis was included as a set of covariates (i.e., categorical variables for time intervals before or after $\mathrm{CM}$ ), modeling the time relative to the occurrence of CM between 14 and 285 DIM. Separate indicator variables were created for every separate DHI test-day record before the CM case and every separate DHI test-day record after the CM case. Hence, the set of binary predictor variables indicated $-3,-2,-1$, or 1,2 , or 3 tests relative to the occurrence of CM. Cows without CM were coded as zero in all these indicator variables. Subsequently, all intermediate variables that were significantly as- sociated with test-day MY in the above-mentioned model were added together to model 5 . Nonsignificant variables were omitted, using a backward stepwise approach to eventually end up with model 4 , corrected for both potential confounders and intermediate variables (defined as model 6).

In all linear mixed models, a first-order autoregressive correlation structure was used to account for the clustering of repeated test days within a heifer. For all linear mixed models, the goodness-of-fit measures included $-2 \times \log$-likelihood, the Akaike information criterion, and the Bayesian information criterion. Residuals were evaluated graphically and graphed against the predicted values. Significance was assessed at $P<$ 0.05 .

\section{RESULTS}

\section{Quarter and Heifer IMI Statuses in Early Lactation}

Overall, $35.7 \%$ of the quarters (483 quarters out of 1,354 from all 344 heifers eligible for inclusion in the study) were infected shortly after calving. Coagulasenegative staphylococci were the most frequently isolated mastitis pathogens $(\mathrm{n}=372 ; 77 \%$ of infected quarters), 
followed by Streptococcus uberis $(\mathrm{n}=48 ; 9.9 \%)$ and Staphylococcus aureus $(\mathrm{n}=38 ; 7.8 \%)$. In total, $29.6 \%$ of the heifers of which the IMI status could be determined ( $\mathrm{n}=240)$ were noninfected and $70.4 \%$ of the heifers were infected with either CNS $(\mathrm{n}=108)$ or a major pathogen $(\mathrm{n}=61)$. The prevalence of CNS-infected heifers was $65.7 \%$ [interquartile range $(\mathbf{I Q R})=50.0$ to 81.7 ] and $56.9 \%$ (IQR $=43.7$ to 71.9$)$ in herds with a low and high 305MY, respectively.

\section{Udder Health in First Lactation}

The overall geometric mean test-day SCC between 14 and 285 DIM was 66,430 cells $/ \mathrm{mL}$ (IQR $=29,500$ to 123,000 cells/mL). Back-transformed test-day $\operatorname{lnSCC}$ of heifers infected with CNS $(65,798$ cells $/ \mathrm{mL})$ tended to be higher compared with noninfected heifers $(54,244$ cells/mL; $P=0.08$ ) and was significantly lower than of heifers infected with a major pathogen in early lactation $(105,383$ cells/mL; $P<0.001$; model 1 and Figure 2).

Across both studies, a total of 25 cases of $\mathrm{CM}$ were reported between 14 and 285 DIM. The average interval from 14 DIM on and the first case of CM was $111 \mathrm{~d}$, with a range of 14 to $273 \mathrm{~d}$. The incidence rate of CM during the first 285 DIM was 4.72 quarter cases/10,000 heifer-days at risk. Heifers infected with CNS tended to have fewer CM cases between 14 and 285 DIM compared with noninfected heifers $(\mathrm{HR}=0.41 ; 95 \% \mathrm{CI}=$ 0.85-4.71; $P=0.13)$, whereas heifers infected with a major pathogen tended to have more $\mathrm{CM}$ cases than noninfected heifers $(\mathrm{HR}=1.99 ; 95 \% \mathrm{CI}=0.13-1.32 ; P$ $=0.13$; model 2 and Figure 3 ). The hazard of getting an NIMI did not differ between noninfected, CNS-infected,

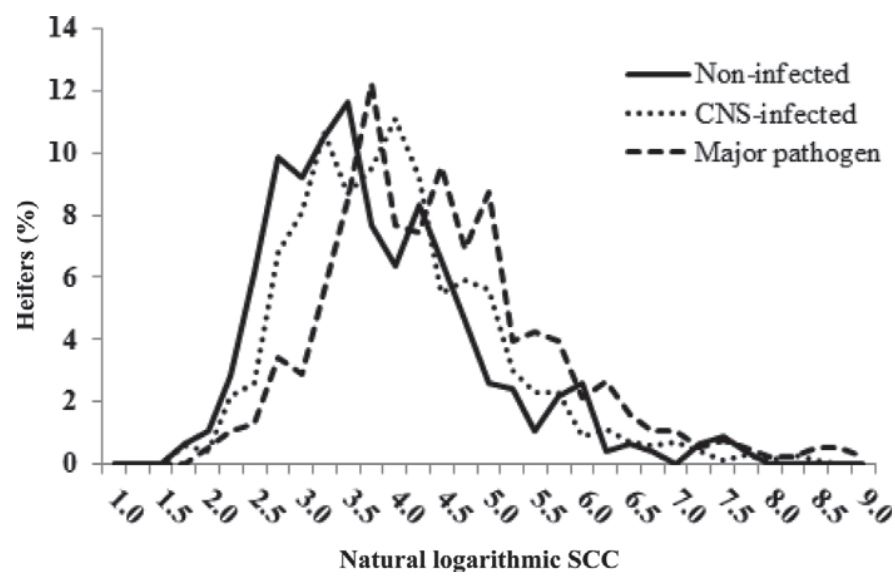

Figure 2. Histogram of the natural logarithmic test-day SCC between 14 and 285 DIM from noninfected, CNS-infected, and major pathogen-infected heifers.

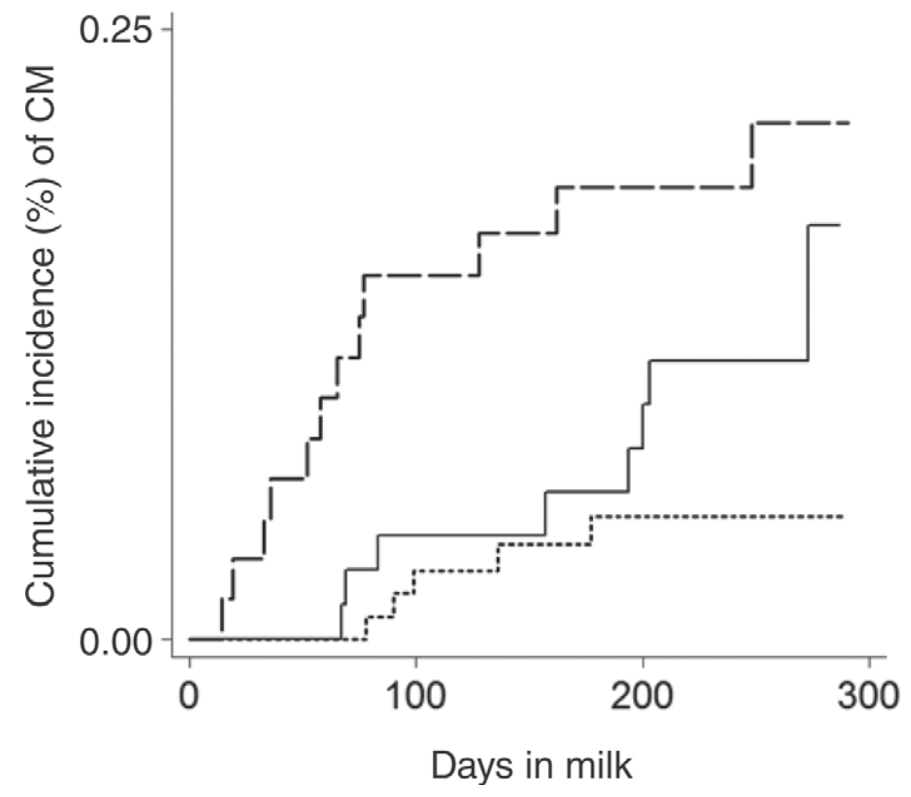

Figure 3. Kaplan-Meier graph of the cumulative incidence of clinical mastitis $(\mathrm{CM})$ in the first 285 DIM for noninfected heifers $(-)$, heifers infected with CNS (----), and heifers infected with major pathogens $(--)$ in early lactation.

and major pathogen-infected heifers $(P=0.34$; model $3)$.

\section{Association Between IMI Status in Early Lactation and Test-Day MY}

Effect of Potential Confounders. The average test-day MY of all heifers between 14 and 285 DIM was $24.3 \mathrm{~kg} / \mathrm{d}$ (IQR $=20.3$ to $28.8 \mathrm{~kg} / \mathrm{d})$. Heifers infected with CNS in early lactation had a significantly higher test-day MY than noninfected heifers (Table 2). The uncorrected positive effect of CNS on test-day MY (model 4) was estimated at $1.32 \mathrm{~kg} / \mathrm{d}$ (Figure 4).

Correcting model 4 for GEN decreased this positive effect to $1.17 \mathrm{~kg} / \mathrm{d}$ (Figure 4). In contrast, including herd in the model resulted in a far more pronounced positive association between test-day MY and being infected with CNS in early lactation (estimated at 2.2 $\mathrm{kg} / \mathrm{d}$; Figure 4). Correcting the model for study and $305 \mathrm{MY}$ also increased the positive effect of CNS IMI to 2.01 and $1.52 \mathrm{~kg} / \mathrm{d}$, respectively. All 4 potential confounders were significantly associated with testday MY when separately added to model 4 . However, when fitting a model including GEN, herd, study, and $305 \mathrm{MY}$, convergence of the model was not reached due to the collinearity between herd and both study and 305MY. Adding 305MY and GEN to model 4 extended with herd as random rather than as fixed effect reduced the variance at the herd level by $41 \%$, suggesting that 
Table 2. Overview of the different linear mixed regression models describing the effect of different potential confounder and intermediate variables on the average test-day milk yield (MY) of heifers between 14 and 285 DIM and on the regression parameter of the heifers' IMI status

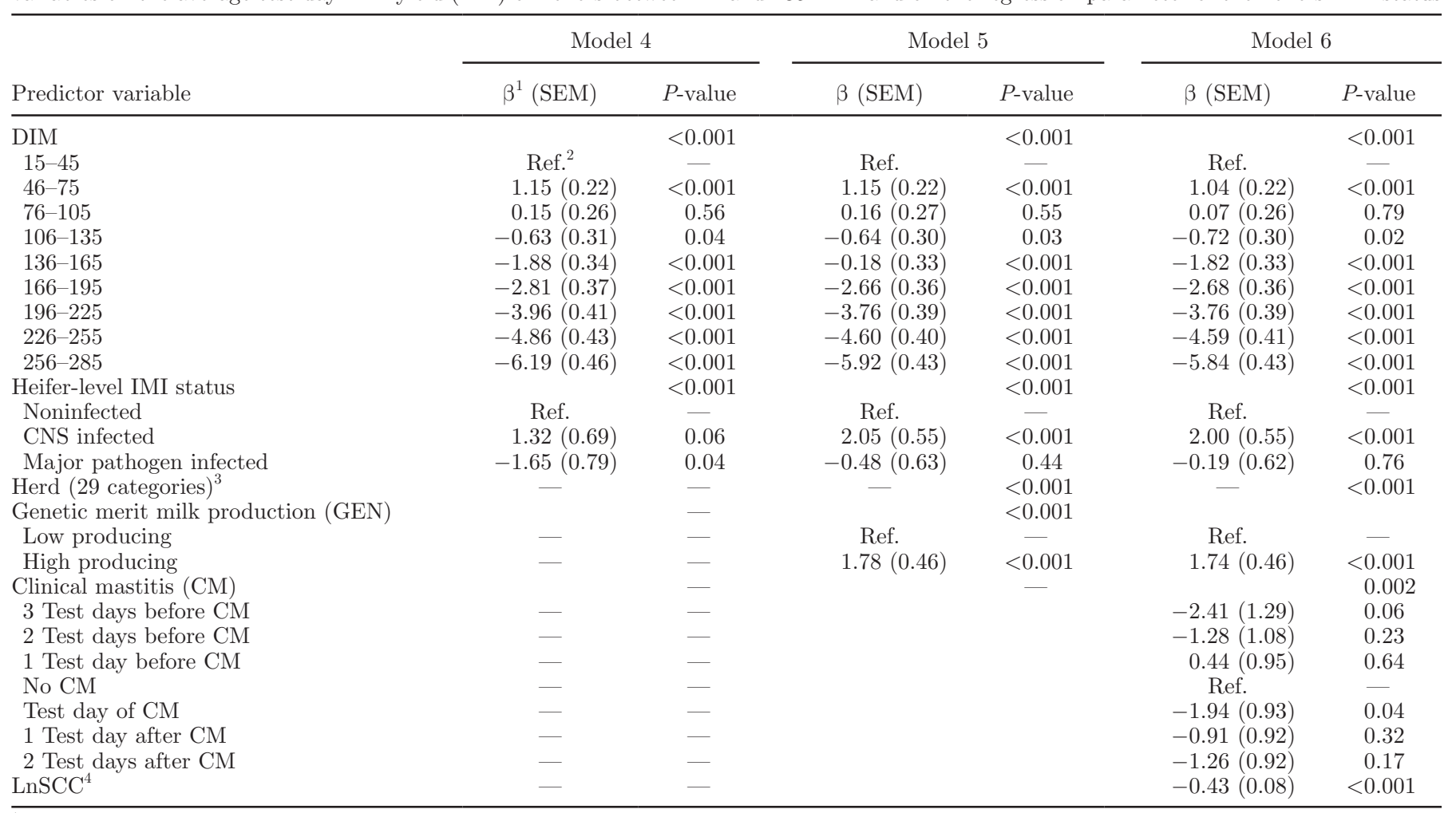

${ }^{1}$ Regression coefficient.

${ }^{2}$ Ref. $=$ reference.

${ }^{3}$ Estimate not shown.

${ }^{4}$ Natural logarithm-transformed test-day SCC.

305MY explained $41 \%$ of the variation in heifers' testday MY between herds. In that model, heifers housed in high-producing herds produced, on average, 4.18 $\mathrm{kg} / \mathrm{d}$ more than heifers from low-producing herds $(P$ $<0.001$ ). Correcting model 4 for both GEN and herd (model 5) resulted in a positive effect of CNS IMI on test-day MY of $2.05 \mathrm{~kg} / \mathrm{d}$ (Figure 4).

Effect of Potential Intermediate Variables. Heifers that contracted a CM between 14 and 285 DIM produced substantially less than herd mates that remained clinically healthy $(P<0.01$; model 6 and Table 2). The tendency toward a lower incidence of $\mathrm{CM}$ in CNS-infected compared with noninfected heifers explained $0.16 \mathrm{~kg} / \mathrm{d}$ of the positive effect of CNS IMI in early lactation on test-day MY throughout lactation after adding $\mathrm{CM}$ to model 5 (Figure 5). Including testday LnSCC in model 5 , to adjust for the significantly higher test-day SCC in CNS-infected heifers compared with noninfected herd mates, increased the estimated positive effect of CNS IMI on test-day MY with 0.11 $\mathrm{kg} / \mathrm{d}$ (Figure 5). The number of estimated NIMI neither influenced the test-day MY nor the association between CNS IMI in early lactation and test-day MY
$(P=0.33)$. Adjusting model 5 for both $\mathrm{CM}$ and testday LnSCC (model 6) resulted in a final explained and unexplained positive effect of 0.05 and $2.0 \mathrm{~kg} / \mathrm{d}$, respectively (Figure 5).

\section{DISCUSSION}

We set out the work reported here to get a better understanding of the somewhat surprising finding that CNS IMI in heifers are associated with an increased MY relative to uninfected herd mates (Piepers et al. 2010), with specific focus on the effect of the heifers' genetically determined milk production level and the incidence of CM. The finding of higher milk productions in CNSinfected animals compared with their noninfected herd mates is consistent with the results published by others (Gröhn et al., 2004; Compton et al., 2007; Schukken et al., 2009; Paradis et al., 2010). To identify potential confounders and intermediate variables, a causal diagram was proposed and 2 precise longitudinal data sets were analyzed using a series of statistical models. Using this approach, it was possible to disentangle potential confounding and intermediate effects from the actual 


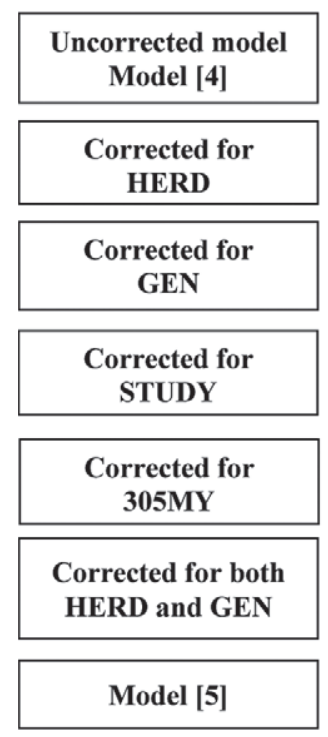

UNCORRECTED PRODUCTION EFFECT CNS

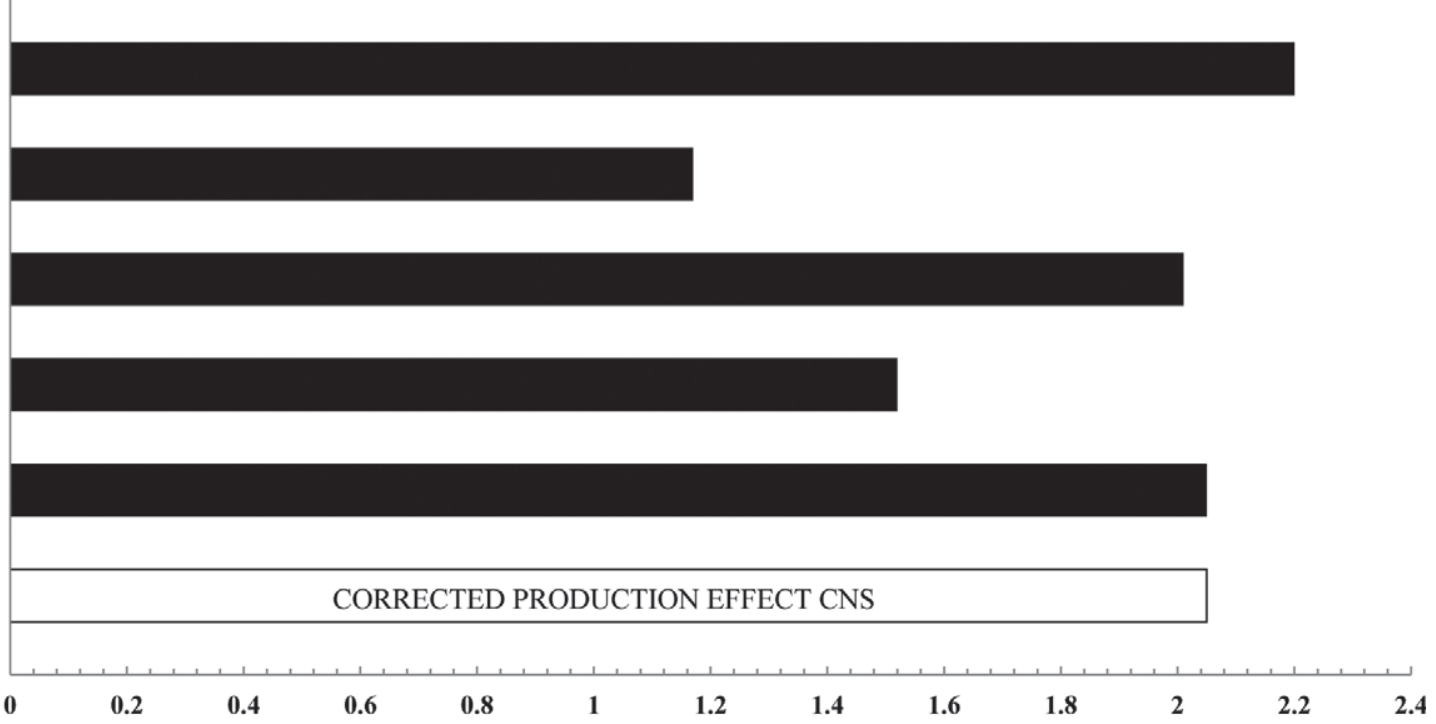

Milk yield (kg/d)

Figure 4. Results of the stepwise analyses including potential confounders of the uncorrected effect of IMI with CNS in early lactation on the heifers' test-day milk yield between 14 and 285 DIM compared with noninfected heifers. The black bars show the milk production effect of CNS IMI corrected for the potential confounder(s) boxed on the left side of the vertical axis. GEN = the genetic milk production of the heifers; $305 \mathrm{MY}=$ the average 305-d milk yield at the herd level.

effect of CNS IMI in early lactation on the heifers' average test-day MY throughout first lactation. Indeed, an essential biological difference exists between confounder and intermediate variables. Confounders create another pathway in the causal diagram and directly affect both the predictor variable of main interest (i.e., IMI in early lactation) and the outcome variable (i.e., test-day MY) and might, thus, manipulate the effect of CNS IMI on test-day MY in either a positive or negative way. An intermediate variable, on the other hand, stands in between the predictor variable of main interest (i.e., IMI in early lactation) and the outcome variable (i.e., testday MY) in the causal diagram and will, thus, rather explain to the same extent why CNS IMI are positively associated with test-day MY. Although both data sets reinforced the potential positive effect of CNS IMI on MY, none of them was originally designed to address the specific hypotheses stated here. Still, these types of data sets and the wealth of information they contain are very useful to test specific hypotheses when combined in such work as reported here. In essence, this is an explorative study of which the findings give further insights into the association between CNS IMI in early lactation and MY throughout first lactation and will give direction for future research on this topic.

Taking GEN, the potential confounder of main interest, into account reduced the estimated MY increase associated with CNS IMI, indicating that animals with a high GEN have indeed a higher likelihood of becoming infected with CNS in early lactation. Gröhn et al. (2004) suggested that CNS are more likely to be contracted by higher-producing cows. Actually, multiparous cows suffering from CM caused by CNS significantly outproduced their healthy herd mates by approximately 2.5 $\mathrm{kg} / \mathrm{d}$ before CM diagnosis (Gröhn et al., 2004). In the current study, heifers with higher GEN had average milk yields that were $1.78 \mathrm{~kg} / \mathrm{d}$ higher than those with low genetic merit. Still, the confounding effect of GEN was relatively small and estimated at merely $0.15 \mathrm{~kg} / \mathrm{d}$. Surprisingly, in an attempt to find an explanation for the positive association between CNS IMI in early lactation and test-day MY throughout first lactation, we came across an even more pronounced association instead. Indeed, correcting for a herd effect, either as a herd indicator (herd) or as the average herd milk production (305MY), unexpectedly increased the average test-day MY associated with CNS IMI. When looking at the data in some more detail, it became clear that herds with a higher proportion of CNS-infected heifers tended to have a lower 305MY. Although the epidemiological behavior of the different CNS species differs (Piessens et al., 2011), CNS isolated from early lactating heifer IMI seems to be more opportunistic (e.g., Staphylococcus simulans and Staphylococcus hemolyti- 


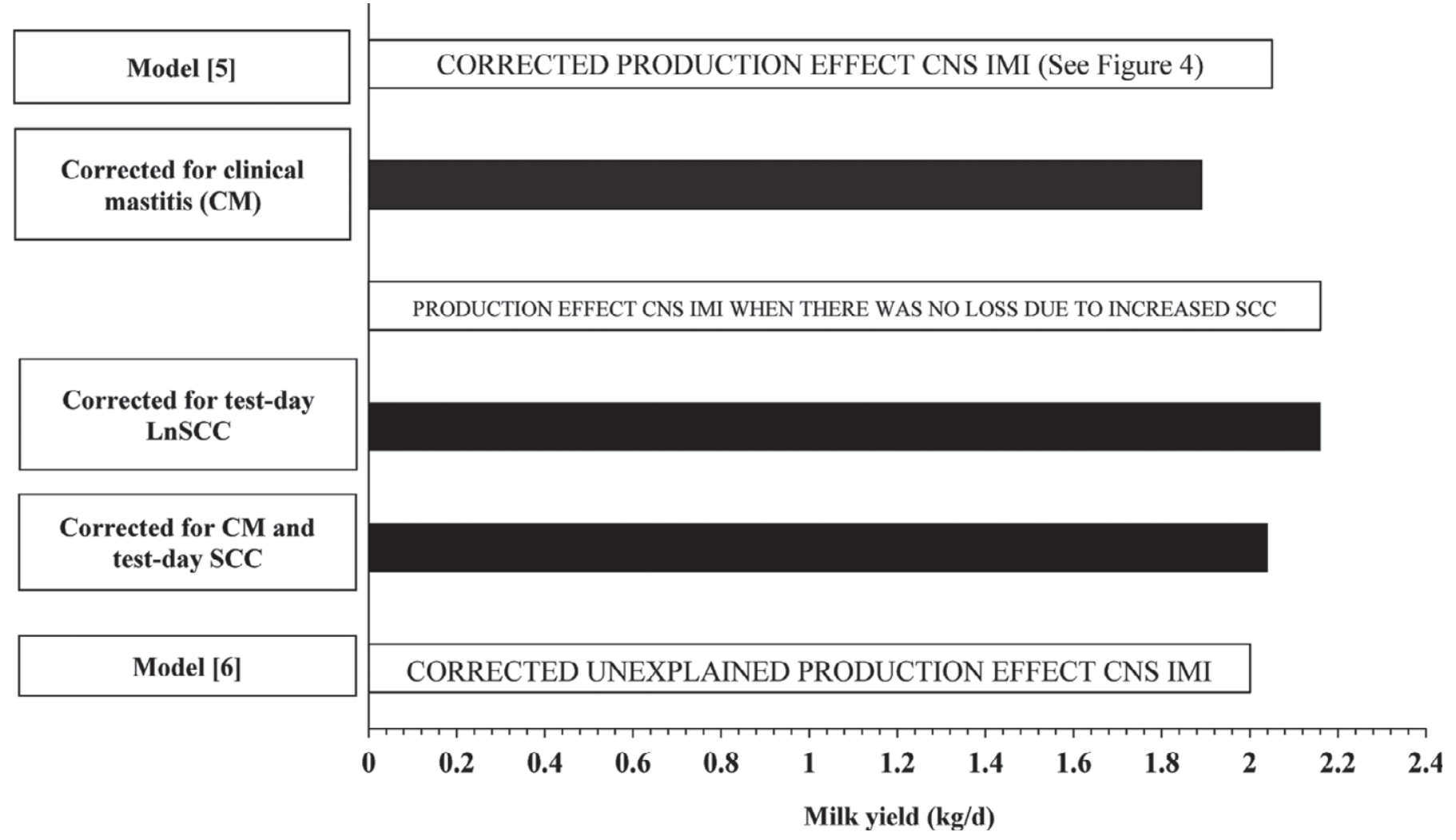

Figure 5. Results of the stepwise analyses including potential intermediate variables of the effect of IMI with CNS in early lactation on the heifers' test-day milk yield, after having corrected for the potential confounders herd and the heifers' genetic merit for milk production (GEN), on the heifers' test-day milk yield between 14 and 285 DIM. The black bars show the milk production effect of CNS IMI after having corrected for the potential confounders herd and GEN corrected for the intermediate variable(s) boxed on the left side of the vertical axis. LnSCC $=$ testday natural logarithm-transformed SCC.

cus) than contagious (e.g., Staphylococcus chromogenes and Staphylococcus epidermidis) in nature (Piepers et al., 2011; Piessens et al., 2011). The lower 305MY might be indicative of a less precise management style (Bigras-Poulin et al., 1985; Enevoldsen et al., 1996), less optimal hygienic conditions, and thus a higher risk for CNS IMI. When taking both animal GEN and both herd effects (herd and 305MY) into account as possible confounders, the within-herd increase in MY of CNSinfected animals relative to their uninfected herd mates was appropriately corrected upward from $1.32 \mathrm{~kg} / \mathrm{d}$ to almost $2.05 \mathrm{~kg} / \mathrm{d}$.

Given this estimate of a $2.05-\mathrm{kg}$ production increase in CNS-infected heifers compared with the uninfected ones, the next step was to try and explain how this effect was realized. By inserting effects that might be considered intermediate variables in the model corrected for GEN and herd, the biological reasons for an increased MY due to a CNS infection might be better understood. We evaluated whether CNS IMI resulted in a lower incidence rate of $\mathrm{CM}$, the intermediate variable of main interest. Heifers that suffered from CM experienced, irrespective of the causative pathogen, a substantial drop in MY of almost $2.0 \mathrm{~kg} / \mathrm{d}$ around disease onset, which corresponds well with previous findings (Gröhn et al. 2004). Although CNS IMI in early lactation were indeed associated with a lower rate of $\mathrm{CM}$, the inclusion of this intermediate variable of main interest only explained a small proportion of the increased average test-day MY. Approximately $0.2 \mathrm{~kg}$ of the 2-kg increase in MY associated with a CNS IMI could be attributed to the intermediate effect of protection against $\mathrm{CM}$ in CNS-infected heifers compared with noninfected ones. Interestingly, the inclusion of another potential intermediate variable, test-day SCC, unexpectedly resulted in an increase in the test-day MY estimate of CNS IMI. As a CNS IMI is associated with an increased SCC, and SCC is negatively associated with test-day MY, the inclusion of SCC in the model appeared to remove the negative SCC effect on test-day MY from the positive CNS IMI production effect. Finally, with appropriate correction for confounders, with GEN as confounder of main interest, and all biologically understood intermediate variables with the 
incidence of $\mathrm{CM}$ as intermediate variable of main interest, an unexplained production increase of $2.0 \mathrm{~kg} / \mathrm{d}$ in heifers with a CNS IMI in early lactation remained.

The observed production effects of CNS IMI are consistent among several studies performed in different countries. Therefore, additional studies that take a different approach to the hypothesized relationship may be of more value. Probably one of the major drawbacks of our study and others is that test-day SCC and MY records during first lactation have been measured at the animal rather than at the quarter level. The differences in test-day MY between heifers might, thus, be due to 1 of the 4 quarters, although that quarter may or may not have been infected with CNS in early lactation. Conducting a longitudinal study on herds with, for example, an automatic milking system would allow for measuring both the IMI status and MY throughout (first) lactation at the quarter level rather than at the heifer level, circumventing the potential introduction of ecological fallacy (Schukken et al., 1988). Also, collecting samples for bacteriological culturing beyond early lactation would allow for a more precise evaluation of the persistence of CNS IMI at calving throughout lactation and the likelihood for developing CM when infected with CNS. Studies where the CNS species would be differentiated by means of accurate molecular techniques might provide insight whether the observed increase is either species specific or true across many CNS species, but this would require extensive sampling and very large studies. Also, the contrary could be true: some CNS species might decrease MY throughout lactation. In this regard, Koop et al. (2012) recently found a positive association between Staphylococcus caprae, a highly prevalent CNS species in dairy goat milk, and MY. On the other hand, IMI caused by Staphylococcus xylosus negatively affected MY in a comparable way as Staph. aureus, although that effect was not significantly different from zero.

Challenge studies with specific CNS isolates would also be helpful in further solidifying the causality of the observed relationship. The design of such a challenge study would be important as the specific presence of CNS IMI at the time of calving may not be easy to recreate using current model systems. A recently published challenge model whereby the mammary gland was challenged in late gestation might provide a model that would reproduce an established CNS IMI at the time of calving (Quesnell et al., 2012).

When CNS IMI after calving are consistently associated with an increased MY, current mastitis control programs may need to be reevaluated. Mastitis prevention and control programs were developed in the 1960s and have ever since been adopted with considerable success in reducing the prevalence of major mastitis pathogens such as Staph. aureus, Streptococcus agalactiae and Strep. uberis in every dairy herd where they have been applied (Hillerton et al., 1995; Bradley, 2002). Still, as the prevalence of those mastitis pathogens was reduced, the proportion of CNS IMI substantially increased in many countries, indicating that CNS IMI are determined by different factors than Staph. aureus and Strep. uberis IMI. In a recent study, risk factors associated with CNS IMI in early lactating dairy heifers were indeed very different from those associated with IMI caused by Staph. aureus (Piepers et al., 2011). Also, heifers that are, based on their genotype, less likely to have IMI due to major mastitis pathogens do not necessarily have fewer IMI caused by CNS, suggesting a pathogen group-specific susceptibility to IMI (Verbeke et al., 2012). Differences in factors associated with CNS IMI and those that are associated with major pathogen IMI could open up perspectives for the selective prevention and control of IMI with major mastitis pathogens. In contrast, risk factors selectively allowing CNS IMI with MY increasing effects could be established.

\section{CONCLUSIONS}

Heifers infected with CNS in early lactation outproduced, yet for unknown reasons, their noninfected herd mates. The observed positive association between CNS IMI and MY was only marginally confounded by the higher genetically determined milk production levels and could only slightly be explained by the lower incidence of CM in CNS-infected heifers compared with the noninfected ones. Interestingly, in an attempt to find an explanation for the somewhat surprising positive association, we ended up with an even more pronounced association between CNS IMI and test-day MY, as the effect was strongly confounded by herd due to a higher prevalence of CNS-infected heifers in herds with a low $305 \mathrm{MY}$ than in herds with a high 305MY. Although the design of the data sets yielded some limitations, the findings suggest that CNS IMI in early lactating heifers indeed positively affect MY throughout first lactation and that this is most probably not related to the heifers' genetically determined milk production or to a difference in likelihood of contracting CM throughout lactation between CNS-infected and noninfected early lactating heifers. When CNS IMI consistently result in an increased MY, current mastitis control programs may need to be reevaluated. Knowing the differential effect of control procedures on CNS IMI and IMI with major pathogens would be of value to the dairy industry.

\section{REFERENCES}

Barkema, H. W., Y. H. Schukken, T. J. Lam, M. L. Beiboer, H. Wilmink, G. Benedictus, and A. Brand. 1998. Incidence of clinical mas- 
titis in dairy herds grouped in three categories by bulk milk somatic cell counts. J. Dairy Sci. 81:411-419.

Bigras-Poulin, M., A. H. Meek, D. J. Blackburn, and S. W. Martin. 1985. Attitudes, management practices, and herd performance A study of Ontario dairy farm managers. I. Descriptive aspects. Prev. Vet. Med. 3:227-240.

Bradley, A. J. 2002. Bovine mastitis: An evolving disease. Vet. J. 164:116-128.

Braem, G., S. De Vliegher, B. Verbist, M. Heyndrickx, F. Leroy, and L. De Vuyst. 2012. Culture-independent exploration of the teat apex microbiota of dairy cows reveals a wide bacterial species diversity. Vet. Microbiol. 157:383-390.

Braem, G., S. De Vliegher, B. Verbist, V. Piessens, E. Van Coillie, L. De Vuyst, and F. Leroy. 2013. Unraveling the microbiota of teat apices of clinically healthy lactating dairy cows, with special emphasis on coagulase-negative staphylococci. J. Dairy Sci. 96:1499-1510.

Compton, C. W. R., C. Heuer, K. Parker, and S. McDougall. 2007. Epidemiology of mastitis in pasture-grazed peripartum dairy heifers and its effects on productivity. J. Dairy Sci. 90:4157-4170.

Cook, W. F., E. A. Fiez, and L. K. Fox. 1992. Mastitis in first lactation southwest Idaho dairy cows. J. Dairy Sci. 75(Suppl. 1):158. (Abstr.)

De Vliegher, S., H. W. Barkema, G. Opsomer, A. de Kruif, and L. Duchateau. 2005a. Association between somatic cell count in early lactation and culling of dairy heifers using Cox frailty models. J. Dairy Sci. 88:560-568.

De Vliegher, S., H. W. Barkema, H. Stryhn, G. Opsomer, and A. de Kruif. 2004. Impact of early lactation somatic cell count in heifers on somatic cell counts over the first lactation. J. Dairy Sci. $87: 3672-3682$.

De Vliegher, S., H. W. Barkema, H. Stryhn, G. Opsomer, and A. de Kruif. 2005b. Impact of early lactation somatic cell count in heifers on milk yield over the first lactation. J. Dairy Sci. 88:938-947.

De Vliegher, S., L. K. Fox, S. Piepers, S. McDougall, and H. W. Barkema. 2012. Invited review: Mastitis in dairy heifers: Nature of the disease, potential impact, prevention, and control. J. Dairy Sci. 95:1025-1040.

Enevoldsen, C., J. Hindhede, and T. Kristensen. 1996. Dairy herd management types assessed from indicators of health, reproduction, replacement, and milk production. J. Dairy Sci. 79:12211236 .

Fox, L. K. 2009. Prevalence, incidence and risk factors of heifer mastitis. Vet. Microbiol. 134:82-88.

Green, L. E., Y. H. Schukken, and M. J. Green. 2006. On distinguishing cause and consequence: Do high somatic cell counts lead to lower milk yield or does high milk yield lead to lower somatic cell count? Prev. Vet. Med. 76:74-89.

Gröhn, Y. T., D. J. Wilson, R. N. Gonzalez, J. A. Hertl, H. Schulte, G. Bennett, and Y. H. Schukken. 2004. Effect of pathogen-specific clinical mastitis on milk yield in dairy cows. J. Dairy Sci. $87: 3358-3374$

Hillerton, J. E., A. J. Bramley, R. T. Shaker, and C. H. McKinnon. 1995. Patterns of intramammary infection and clinical mastitis over a 5 year period in a closely monitored herd applying mastitis control measures. J. Dairy Res. 62:39-50.

Hogan, J. S., K. L. Smith, D. A. Todhunter, and P. S. Schoenberger. 1988. Rate of environmental mastitis in quarters infected with Corynebacterium bovis and Staphylococcus species. J. Dairy Sci. 71:2520-2525.

Koop, G., S. De Vliegher, A. De Visscher, K. Supré, F. Haesebrouck, M. Nielen, and T. van Werven. 2012. Differences between coagulase-negative Staphylococcus species in persistence and in effect on somatic cell count and milk yield in dairy goats. J. Dairy Sci. 95:5075-5084.

Matthews, K. R., R. J. Harmon, and B. E. Langlois. 1991. Effect of naturally occurring coagulase-negative staphylococci infections on new infections by mastitis pathogens in the bovine. J. Dairy Sci. 74:1855-1859.
Paradis, M.-È., É. Bouchard, D. T. Scholl, F. Miglior, and J.-P. Roy. 2010. Effect of nonclinical Staphylococcus aureus or coagulase-negative staphylococci intramammary infection during the first month of lactation on somatic cell count and milk yield in heifers. J. Dairy Sci. 93:2989-2997.

Parker, K. I., C. W. Compton, F. M. Anniss, A. Weir, C. Heuer, and S. McDougall. 2007. Subclinical and clinical mastitis in heifers following the use of a teat sealant precalving. J. Dairy Sci. 90:207-218.

Piepers, S., L. De Meulemeester, A. de Kruif, G. Opsomer, H. W. Barkema, and S. De Vliegher. 2007. Prevalence and distribution of mastitis pathogens in subclinically infected dairy cows in Flanders, Belgium. J. Dairy Res. 74:478-483.

Piepers, S., S. De Vliegher, A. de Kruif, G. Opsomer, and H. W. Barkema. 2009. Impact of intramammary infections in dairy heifers on future udder health, milk production, and culling-Review. Vet. Microbiol. 134:113-120.

Piepers, S., G. Opsomer, H. W. Barkema, A. de Kruif, and S. De Vliegher. 2010. Heifers infected with coagulase-negative staphylococci in early lactation have fewer cases of clinical mastitis and higher milk production in their first lactation than non-infected heifers. J. Dairy Sci. 93:2014-2024.

Piepers, S., K. Peeters, G. Opsomer, H. W. Barkema, K. Frankena, and S. De Vliegher. 2011. Pathogen group specific risk factors at herd, heifer and quarter levels for intramammary infections in early lactating dairy heifers. Prev. Vet. Med. 99:91-101.

Piessens, V., E. Van Coillie, B. Verbist, K. Supré, G. Braem, A. Van Nuffel, L. De Vuyst, M. Heyndrickx, and S. De Vliegher. 2011. Distribution of coagulase-negative Staphylococcus species from milk and environment of dairy cows differs between herds. J. Dairy Sci. 94:2933-2944.

Quesnell, R. R., S. Klaessig, J. L. Watts, and Y. H. Schukken. 2012. Bovine intramammary Escherichia coli challenge infections in late gestation demonstrate a dominant antiinflammatory immunological response. J. Dairy Sci. 95:117-126.

Reyher, K. K., D. Haine, I. R. Dohoo, and C. W. Revie. 2012. Examining the effect of intramammary infections with minor mastitis pathogens on the acquisition of new intramammary infection with major mastitis pathogens-A systematic review and meta-analysis. J. Dairy Sci. 95:6483-6502.

Schukken, Y. H., H. N. Erb, P. M. Sears, and R. D. Smith. 1988. Ecologic study of the risk factors for environmental mastitis in cows. Am. J. Vet. Res. 49:766-769.

Schukken, Y. H., R. N. González, L. L. Tikofsky, H. F. Schulte, C. G. Santisteban, F. L. Welcome, G. J. Bennett, M. J. Zurakowski, and R. N. Zadoks. 2009. CNS mastitis: Nothing to worry about? Vet. Microbiol. 134:9-14.

Schukken, Y. H., K. E. Leslie, D. A. Barnum, B. A. Mallard, J. H. Lumsden, P. C. Dick, G. H. Vessie, and M. E. Kehrli. 1999. Experimental Staphylococcus aureus intramammary challenge in late lactation dairy cows: Quarter and cow effects determining the probability of infection. J. Dairy Sci. 82:2393-2401.

Supré, K., F. Haesebrouck, R. N. Zadoks, M. Vaneechoutte, S. Piepers, and S. De Vliegher. 2011. Some coagulase-negative Staphylococcus species affect udder health more than others. J. Dairy Sci. 94:2329-2340.

Verbeke, J., S. Piepers, L. Peelman, M. Van Poucke, and S. De Vliegher. 2012. Pathogen-group specific association between CXCRY1 polymorphisms and subclinical mastitis in dairy heifers. J. Dairy Res. 79:341-351.

Wilson, D. J., R. N. González, J. Hertl, H. F. Schulte, G. J. Bennett, Y. H. Schukken, and Y. T. Gröhn. 2004. Effect of clinical mastitis on the lactation curve: a mixed model using daily milk weights. J. Dairy Sci. 87:2073-2084.

Zadoks, R. N., H. G. Allore, H. W. Barkema, O. C. Sampimon, G. J. Wellenberg, Y. T. Gröhn, and Y. H. Schukken. 2001. Cow- and quarter-level risk factors for Streptococcus uberis and Staphylococcus aureus mastitis. J. Dairy Sci. 84:2649-2663. 